\title{
Capital investment of overseas Vietnamese to the economy of the Socialist Republic of Vietnam
}

\author{
Andrey E. Tyabaev ${ }^{1}$ a, Svetlana F. Sedelnikova ${ }^{1}$, Nguyen Thị Hong Bach Lien ${ }^{1}$, Yaroslav N. Lopukhin ${ }^{2}$. \\ ${ }^{1}$ Tomsk polytechnic university, 634050 Lenina Ave., 30, Tomsk, Russia \\ ${ }^{2}$ Tomsk state university, 634050 Lenina Ave., 36, Tomsk, Russia
}

\begin{abstract}
The paper explores the vital issues of attracting investment from Vietnamese emigrants of different generations to the economy of the present-day Vietnam. We give the definition of the Vietnamese Diaspora (Viet Kieu) and a short overview of emigrant waves. In addition, we explain how leaders of the Socialist Republic of Vietnam have interacted with overseas Vietnamese and their organizations in the field of economy over the years. The paper demonstrates geographic differences existing in this type of investment. Further, we outline the measures taken to encourage the Viet Kieu investment in the country's economy as well as the success rate of these measures. Finally, we specify the barriers to investing in the national economy of Vietnam for "overseas fellow nationals".
\end{abstract}

\section{Introduction}

A characteristic feature of the current economic processes is the increasing role of Diasporas in the international cooperation. Attracting and effective use of the economic and creative potential of "overseas fellow nationals" to develop national economies is a topical question for the leaders of many countries. This paper explores the contribution of the overseas Vietnamese Diaspora to the investment in the economy of Vietnam.

First, let us settle on the very content of the term "diaspora". There are different approaches to the understanding of the term "diaspora" in the current scientific literature [1,2]. Since our article focuses on the role of the Vietnamese Diaspora in modernizing the economy of Vietnam, we will only define the notion of Viet Kieu. Viet Kieu are ethnic Vietnamese living outside Vietnam and permanently reside in other countries. There are over 4.5 million Vietnamese currently living in 109 countries (Table 1), and their annual income combined is comparable to the whole GDP of Vietnam [3].

Ethnologist S.A. Arutyunov wrote in one of his works on diasporas: "If we take into account their constant numerical growth, dynamism, increasingly active economic, political, cultural and intellectual connections, various contacts between people and organizations (including the "highest tiers") in both the countries of origin and the receiving states, their role in the modern world is hard to overestimate" [4]. We can add that the scale of involvement of the Diaspora in the country affairs depends to the greatest extent on its size, the term of living overseas and the accumulated potential [5].

\section{Features of Vietnamese Diaspora}

In the history of world migrations, the Vietnamese Diaspora is relatively young. The Vietnamese nation has been through many hard and even tragic events throughout its history, which resulted in the emergence of a large Vietnamese Diaspora in many countries of the world. Let us outline the episodes of large-scale migrations overseas in the history of Vietnam:

- The first overseas Vietnamese community dates back to the end of 17th century, when the army and the family of the Nguyen dynasty fled to Siam (now Thailand)

- 1914-1918. The second migration stemmed from the French colonization of Indochina. During the World War I, Vietnamese people were transported to Europe, since the French needed soldiers and low-cost labor. Some 400 thousand Vietnamese currently live in France. The French Diaspora is regarded as the oldest and the most affluent one in Europe.

- 1975-1979. These were the years when the proAmerican government of Saigon fell, triggering the most massive migration in the history of the Vietnamese nation. Around 125 thousand people left Vietnam in spring 1975. Americans evacuated the Vietnamese on their staff and supporters of the South Vietnam government with their families in an organized way, on ships and planes.

\footnotetext{
$\overline{{ }^{a} \text { Corresponding author: aet@tpu.ru }}$
} 
- Since the seventies of the 20th century the fourth category formed. This category consists of Vietnamese working and studying in the former Soviet bloc who opted to stay there after the Soviet collapse. This group is found mainly in the European Union (particularly countries formerly aligned with the Soviet Union in the Warsaw Pact) and the Russian Federation.

- Recently a new group of Vietnamese has been emerging. These naturally born Vietnamese who attended high school and college overseas (international student), are called by natives as "du học sinh"; they stay in those countries, work and live there as permanent residents.

- The last category consists of recent economic migrants who work in regional Asian countries such as Taiwan and Japan. They also include Vietnamese brides who married men from Taiwan and South Korea through marriage agencies. These brides usually follow their husbands to live in those countries. In Taiwan, Vietnamese economic migrants constitute most of the overseas Vietnamese there.

The number of the Vietnamese leaving the country increased during the years of socialist reforms. Currently, this is the largest Vietnamese community outside Vietnam. According to the USA census of 2010, $1,727,300$ people identified themselves as Vietnamese.

As a rule, those who emigrated were affluent and educated people of high social status, crume de la crume of South Vietnam. Most of them live in the most economically developed countries: the USA, France, Australia, and Germany.

Table 1. Overseas Vietnamese in the World [6].

\begin{tabular}{|l|l|}
\hline \multicolumn{1}{|c|}{ Country } & $\begin{array}{c}\text { Number of } \\
\text { Vietnamese }\end{array}$ \\
\hline USA & 1727300 \\
\hline Cambodia & 600000 \\
\hline France & 350000 \\
\hline Australia & 250000 \\
\hline Taiwan & 200000 \\
\hline Canada & 157450 \\
\hline Germany & 150000 \\
\hline South Korea & 143000 \\
\hline Russia & 140000 \\
\hline Japan & 136000 \\
\hline Czech Republic & 80000 \\
\hline Malaysia & 70000 \\
\hline Czech Republic & 61000 \\
\hline United Kingdom & 55000 \\
\hline Poland & 50000 \\
\hline Laos & 30000 \\
\hline China & 22500 \\
\hline Norway & 21700 \\
\hline Netherlands & 20600 \\
\hline United Arab Emirates & 20000 \\
\hline Sweden & 16600 \\
\hline
\end{tabular}

Many of them have succeeded in business, holding senior positions in major companies or elected as highranking government officials. These are 300,000 worldclass specialists with profound knowledge of modern science, technology, and languages as well as a large amount of capital. This is what Vietnam badly needs to develop its economy. [7]. Moreover, leaders and activists become mediators of political communication with the state they live in, lobby the interest of the groups they represent in the corridors of power, create the advertising image of Vietnam and tourist products of the Vietnamese origin, which plays a considerable part in the investment strategy of Vietnam.

\section{Vietnamese government's policy of attracting investments from Vietnamese Diaspora}

Active economic transformations being led by Vietnam from a strict Soviet-style socialist model to the market economy (like in China) began in 1990. Despite government efforts, the development of industry in the conditions of socialism went on slowly. The country remained, predominantly, agrarian. The greatest development got such industries as food, consumer goods, mechanical engineering, mining, cement, chemical fertilizers, and oil ones. One of the main tasks in the first years of market reforms was to attract investment in the economy from the countries of Western Europe, North America, Australia, and Japan, where a large number of Vietnamese were living permanently.

During reforms, the government of the Socialist Republic of Vietnam (SRV) came to understanding that an influential overseas Diaspora was in the national interests of Vietnam. Therefore, the leaders of the country changed their attitude to Vietnamese emigrants at that time. The state's stand on the relations with Viet Kieu is becoming increasingly reasonable and active. The government has declared their overseas nationals an integral part of the Vietnamese nation who should keep in touch with their historical homeland and take diligent efforts in the economic life of the country, especially in the investment sphere. The government of Vietnam has taken a number of measures with the following aims:

- to raise more funds in the form of overseas investments (OI) and attract managerial experience to improve business start-up possibilities;

- to encourage business relationships between local and international companies in order to share skills and technologies.

The government has established a State Committee on Viet Kieu Affairs under the Ministry of Foreign Affairs chaired by Vice Minister of Foreign Affairs. The main function of the State Committee is to interact with the Vietnamese Diaspora to mobilize its resources for the benefit of the country's social and economic development. The objective of this committee is to take various measures, including the level of the legal system in the Socialist Republic of Vietnam, in order to attract overseas Vietnamese to economic activity within the country. [8].

Foreign exchange supply to Vietnam is also expected to be boosted from rising foreign direct investment and investment in equities, which could help lead to a surplus of $\$ 8$ billion in the country's balance of international 
payments. Currently, the funds coming from the overseas Vietnamese community account for a significant share of the Vietnamese economy: $8 \%$ of gross national product in 2014 [9].

Some of the important factors of attracting the funds of Viet Kieu to modernize the economy of Vietnam include the measures taken by the state to create and develop the necessary legal framework. The state has passed a number of laws and decrees:

- In November 1999, the Viet Kieu gained the right to invest in Vietnam.

- In September 2007, the overseas ethnic Vietnamese and their next of kin were granted a visa exemption.

- Starting November 2008, the Viet Kieu can keep the citizenship of the state of their permanent residency when applying for the Vietnamese citizenship.

- Since June 2009, the Viet Kieu have had the right to acquire real estate and land, start their own companies based on provisions of the Law on the Promotion of Domestic Investment. Moreover, national business owners have profit tax reliefs $(20 \%$ smaller tax than any other overseas investor) as well as tax reliefs for the repatriation of profits [7].

Since 2002, the trend has been toward the increase in the capital inflow from the Vietnamese Diaspora in major industrial countries to Vietnam. In 2004, the inflow reached US\$1.25 billion. In 2006, it was 3.95 billion, and at the beginning of 2008, already 5.15 billion, which accounted for $7.72 \%$ of the GDP of the Republic of Vietnam. In 2015, the investment volume has reached \$13-14 billion within over three thousand projects [9].

A large number of enterprises are successfully developing with some turning into businesses with major brands like Vingroup and Eurowindow. The Viet Kieu predominantly invest in agriculture, medicine, education, real estate, hotel business, and tourism. So far, these are small-scale investment projects with shorter payback periods, which are mostly aimed at developing the domestic market of the country.

The most significant projects are $\mathrm{Ba} \mathrm{Na}$ cable cars in Da Nang and Dalat Edensee Lake Resort in Dalat. Many overseas Vietnamese businesspeople are chief stockholders of major banks and corporations in Vietnam, such as Techcombank, VPbank, Melinh plaza, and Masan.

The SRV Deputy Foreign Minister Nguyen Thanh Son notes the rise in remittances from the Viet Kieu. Since 1999, the sums of foreign currency transferred have been going up $20 \%$ annually. In 2001, when the government abolished the $5 \%$ tax on the Viet Kieu's remittances, it led to the annual increment reaching 35$40 \%$. According to the data by the State Bank of Vietnam as of 2014, the Vietnamese Diaspora transferred an estimated US\$12 billion money to Vietnam and this figure is expected to reach 13-14 billion in 2015 .

According to a survey by the Central Institute for Economic Management, about $57 \%$ of the total amount of remittances fell on the share of the USA Diaspora in
2010-2012; another 8.4\% came from Canada; $6 \%$ from Germany; and 4\% from France [10].

Remittances serve as a valuable source of investments in charitable organizations for children, elderly people, low-income families, churches, and schools (e.g. SAVICE associations of Viet Kieu in the USA).

Secondly, this is a stable source of currency supply, which helps fund the real economy. Almost 16\% of remittances from overseas Vietnamese are invested in business and $20 \%$ in real estate. On July 1, 2015, the housing law allowed nonresidents and the Viet Kieu to purchase homes and land in Vietnam. This jump-started the real estate market. Remittances in this sphere are expected to increase significantly in the near future.

However, there are some notable difficulties facing the Vietnamese Diaspora when buying land and houses:

- It is hard for many of the new generation of Viet Kieu to prove their Vietnamese origins (because their ancestors lost their papers and they do not speak Vietnamese).

- Viet Kieu have a right to own land and homes for 50 years only.

- Viet Kieu may not own more than $30 \%$ of apartments in one building.

These difficulties make the overseas Vietnamese uncertain when purchasing land and real estate; therefore, they often buy on credit rather than pay cash.

The Vietnamese Diaspora also invests in the development of tropical agriculture and enterprises involved in harvesting and processing of seafood, which promotes the growth in the manufacture of products of "ethnic trade", i.e. export of goods for the Diaspora consumption. Moreover, many members of the Diaspora own Vietnamese national cuisine restaurants, make use of an established distribution network overseas and can contribute to sales and promotion of goods in the domestic markets.

This provides the Vietnamese exporters with their own stable niche in the segment of export trade. Even now, the USA is the largest importer of pangasius from Vietnam, and the annual growth rate of seafood supply to the USA is $10 \%$. Seafood production has become an important part of the revenue in the national economy, in general, and it is particularly attractive for investors.

Enterprises and businesses with the Viet Kieu participation are predominantly located in the south of the country, in Ho Chi Minh City as well as Dong Nai and Binh Duong Provinces. One of the important reasons for this is that the south of Vietnam is home to many Vietnamese who keep in touch with their fellow nationals abroad.

The emigrant community shares the advanced knowledge and experience in business, sales, and marketing. The South Vietnamese are more mobile, still good at doing private business and they often attract the capital of their overseas relatives.

It is also noteworthy that the local authorities of South Vietnam are known as the most active and economically competent. Therefore, the regions of South Vietnam have shown the best economic growth rates and 
attracted almost ten times as much per capita private investment as the Northern regions.

The state government is also interested in using the intellectual potential of the Vietnamese Diaspora. Some 300 thousand of its representatives have academic degrees in various fields. Emigrants provide a lot of assistance in education, training and retraining personnel at home and abroad as well as share professional and managerial skills of doing business. The University of Sydney opened the faculties of Computer Science and Business Administration in Ho Chi Minh City with professors of Vietnamese origin from the Australian University on the staff. The annual number of Vietnamese who leave to study in the USA has tripled lately with the help of the fellow nationals that are permanent residents of America.

Overall, these examples show the obvious contribution of the Diaspora in the form of direct economic and humanitarian assistance to their historical homeland. Many overseas Vietnamese who returned to their homeland founded many branches of science and economy and became well-known and successful businesspeople. This is a positive trend.

At the same time, the cash inflow from the USA Viet Kieu to Vietnam only accounts for $1.9 \%$ of their total income; from Australia, it is 3\%; and from France - 5\% [7]. These figures show that the funds of the Vietnamese community attracted to the economy of the country are insufficient, especially from the USA Viet Kieu. This stems from the legacy of the Vietnam War (1965-1975). The factor of distrust creates tension in the interaction between the overseas Vietnamese communities and their homeland and reduces the inflow of the Viet Kieu's funds.

Over the recent years, the Socialist Republic of Vietnam has been pursuing an active investment policy of attracting the funds of overseas Vietnamese. There are teleconferences on the Viet Kieu investments in Vietnam; a Fund for Overseas Vietnamese Community and Business Association of Overseas Vietnamese were established; the government arranges official meetings with overseas fellow nationals [11].

A forum themed "The overseas Vietnamese intellectuals and experts contribute opinions to the country's economic development and integration during the 2016-2020 period" started its work in 2015. On June 7,2015 , there were meetings held as part of this forum with the organizations of the overseas Vietnamese Diaspora [3]. More than 100 overseas Vietnamese (specialists in economics from universities of the USA, France, Australia and Japan or from major banking organizations, etc.) joined their domestic colleagues to discuss the challenges of restructuring the economy, improving the administration, reforming the financial system and higher education, training qualified specialists, developing the industrial policy, agriculture, and business.

\section{Conclusion}

Vietnam has gone through three major migration waves, two of which occurred in the twentieth century. Emigrants have achieved great success in the economy, science and technology in their new countries. Modern Vietnam considers it necessary to involve the Vietnamese emigrants to participate in economic projects, as well as in the development of science and higher education. The greatest progress has been made in the southern part of the country. Despite many years of activity and some degree of success, the leaders of the Socialist Republic of Vietnam are facing a challenge of developing such investment strategy that would facilitate maximum attraction of material and other resources of the Vietnamese Diaspora to the modernization of the country without peaking the contradictions between the old and new elites of Vietnam.

\section{References}

1. R. Cohen, International Encyclopedia of the Social \& Behavioral Sciences (Second Edition) (2015)

2. E. L-E. Ho, M. Hickey, B.S.A. Yeoh, Geoforum, 59, (2015)

3. Bùi Hằng, Dai Tieng Noi Viet Nam, 08, (2015)

4. S.A. Arutyunov, S.Ya Kozlov, Nezavis. Gazeta, November 23, 5 (2005)

5. J. Priebea, R. Rudolf, World Dev., 760 (2015).

6. CIA - The World Factbook. URL: https://www.cia.gov/library/publications/the-worldfactbook/

7. M.H. Pham, Ekonom. nauki, 2б (2010)

8. Michael G. Plummer, J. of Asian Ec., 6, 3 (1995)

9. B.M. Ho, Reuters, January 12 (2015).

10. Statistics of the Ministry of Foreign Affairs of Vietnam, Vietnam Ministry of Foreign Affairs URL: http://www.mofa.gov.vn/en (Accessed 02/02/2016)

11. D.H. Nguyen, Nhip cau the gioi, 17 (2009) 